\title{
Elections in Botswana: A Ritual Enterprise?
}

\author{
Mokganedi Zara Botlhomilwe*,1 and David Sebudubudu*,2 \\ ${ }^{I}$ Department of Sociology, University of Botswana, Botswana \\ ${ }^{2}$ Department of Political and Administrative Studies, University of Botswana, Botswana
}

\begin{abstract}
Botswana has the reputation of being Africa's longest surviving democracy having held uninterrupted elections at five year intervals since the pre-independence elections of 1965. The latest elections were held in October 2009. Although in democratic discourse it is assumed and/or expected that the holding of regular free, fair and competitive multiparty elections should provide an opportunity of regime change, this has so far not materialized in Botswana. The country is therefore a dominant-party system with only one political party, the Botswana Democratic Party (BDP), having won all the elections held so far. This paper argues that there is nothing inherently undemocratic with people voting for the same political party provided the political playing field is level. A number of factors are advanced to explain the dominance of the BDP in the country's politics. These include, inter alia, the perceived delivery of the ruling party, the politics of patronage, advantages of incumbency and other factors related to the culture of Batswana. Having said this, it is concluded that recent political events in the country point towards the emergence of a new undemocratic culture which may result in the reversal of the system of one-party dominance. Thus, it is argued that the dominance of the BDP in the country's politics is likely to be seriously challenged in the not too distant future.
\end{abstract}

Keywords: Elections, incumbency, fragmented opposition, one-party dominance, tolerance, democracy.

\section{INTRODUCTION}

Since Botswana attained formal independence from Britain in 1966, it has distinguished itself from many postindependent African states by embracing the liberal democratic tradition. In fact, the constitution of Botswana declares Botswana as a Republic. This means that citizens have the right to choose their leaders at certain intervals. Unlike many African countries, it has never experienced a military coup, dictatorship or one-party system of governance. The postponement of elections has also never been a feature of the politics of Botswana. Save for the 1965 elections, which were called a year early, subsequent elections have been held every five years as provided in the country's constitution. This partly reflects the elites' commitment to the constitution and the rule of law. Sadly, the multiparty competitive elections held so far have failed to produce a turn-over of government. Thus, Botswana still has to pass Samuel Hungtington's two turn-over test of a consolidated democracy. Botswana therefore remains a one-party dominant system where the BDP has won all the general elections held since 1965. Interestingly, the BDP has not been tempted, as occurred in Kenneth Kaunda's Zambia and Kamuzu Banda's Malawi, to take advantage of its strength to declare a one party state. It should be noted that when the authoritarian regimes of Zambia and Malawi re-introduced multi-party politics and

*Address correspondence to these authors at the Department of Sociology, University of Botswana, Gaborone, Botswana; Tel: +2673552765; Fax: +2673554196; E-mail: Botlhomz@mopipi.ub.bw

Department of Political and Administrative Studies, University of Botswana, Gaborone, Botswana; Tel: +2673552742; Fax: +2673552463; E-mail: Sebudubu@mopipi.ub.bw lost the elections, they accepted the outcome of those elections. This development should be sufficient to give one the optimism that the BDP will accept the people's verdict in the event of electoral defeat given its high level of opposition tolerance spanning over four decades.

The paper argues that although a multi-party electoral framework has been in operation in Botswana since independence, it has not resulted in any alternation in government between political parties. However, there has been a change of leadership within the BDP with Ketumile Masire handing over the presidency to Festus Mogae in 1998 and the latter to Ian Khama in 2008, thanks to the system of automatic succession. It observes a trend of the Botswana electorate seemingly beginning to vote on the basis of economic considerations. The dominance of the BDP is explained, among other things, in terms of the influence of Seretse Khama, the advantages accruing to the BDP by virtue of being the governing party, and a weak and fragmented opposition. The paper concludes by arguing that the recent political developments within the BDP have probably provided the first significant opportunity for the emergence of a serious electoral challenge to the BDP dominance.

The latest general election in Botswana was held in October 2009. As was expected, the BDP once again emerged victorious. For a country that has been holding reasonably free competitive multi-party elections since 1965 , it is perhaps surprising that it has so far failed to produce an alternative government. The importance of the electoral process in a democratic set-up can not be overemphasized. Dalton and Gray [1] argue that although there are other forms of public participation and influence in democracies, it is the elections that provide the primary forum for such exercise: 
The critical difference between authoritarian states and democratic regimes is that in the latter residents can freely and fairly select representatives and in some cases directly decide public policies through the referendum and initiative. Modern representative democracies are thus built upon the electoral process. The voters' choice between competing parties or candidates is still the primary basis of public access and influence in contemporary democracies. Moreover, participation in elections is typically the most common form of political engagement ( $\mathrm{p} 23)$.

Dalton and Gray [1] further argue that the electoral process is superior to other forms of engagement in terms of 'quality of collective representation and democratic legitimacy'. According to Savage and Warde [2], demonstrations and riots are other forms of engagement but are not regarded as the most efficient and civilized forms of engagement with the state. Thus, elections are part and parcel of any democratic dispensation. The importance of elections can also be found in what they are capable of deciding. Dalton and Gray [1] maintain that:

Elections are also important for what they decide. Electoral outcomes determine who manages affairs of government and who makes public policy. The selection of leaders and the ability to 'throw the rascals out' at the next election are the public's ultimate instruments of non-violent power. Political elites may not always act as they promise, but the selection of a government provides some popular control over them. Moreover, campaign debates are among the prime mechanisms for ensuring openness and accountability in the political process. Indeed, the competitive nature of electoral politics encourages citizens to discuss the policies of the government and the behaviour of potential policy-makers (p 23).

Competitive elections are therefore an important ingredient of any polity that claims to be democratic. Kotze and Garcia-Rivero [3] maintain that in the absence of opposition, there can be no democracy in that 'for a democracy to function properly, it needs an opposition to provide political contestation and electoral competition, thus limiting the power of the ruling party' ( $p$ 454).

Thus, elections in Botswana are still to provide what is normally expected of competitive electoral politics, namely, providing a robust challenge to the rule of the BDP. Any attempt to account for the continued predominance of the BDP in Botswana's politics as evidenced once again in the recent general election of October 2009 will invariably involve a discussion of the problems encountered by opposition parties that militate against their ability to seriously challenge the hegemony of the BDP.

\section{Economic Performance and Voting Trends}

There is a consensus among scholars that one of the tests for a democracy in a particular polity is the ability of the political system to provide an opportunity for an alternative government. The logic behind this argument is that where an open and fair system of competitive and periodic fair elections is in operation, it should be possible for the electorate to punish a non-performing governing political party by voting for other parties. This argument is probably partially derived from the reward/punish model of voting that is common in industrialized democracies. According to Swank and Eisinga [4], this 'responsibility hypothesis' model holds that in times of economic prosperity the electorate reward the party in government by voting for it and punish it by redirecting their vote to other political parties in times of economic difficulties. Johnston and Pattie [5] argue that this model 'implies that government parties should lose support from those feeling financially disadvantaged by their policies but should gain it from those who are benefiting but formerly supported another party' ( $p$ 47). This model of voting suggests that voters' economic evaluations guide their voting behaviour.

In a review of economic and political developments in Botswana in the years 1989, 1994 and 1999, Matsheka and Botlhomilwe [6] found that Batswana are now voting largely with economic considerations in mind and that 'unqualified emphasis on ethnicity and patron-client relationships as important variables in explaining party choice can longer be sustained'. This is not to deny that electoral choices are based on a multiplicity of factors such as party affiliation, but that the bulk of academic literature on voting behaviour in Botswana has tended to place disproportionate weight on political factors at the expense of economic considerations. In the 1989 election year, the BDP obtained $65 \%$ of the vote and at that time the elections took place upon favourable economic conditions ever enjoyed in the country. The Bank of Botswana [7] stated that 'the year 1989 marked the end of a decade that would stand out in the economic history of Botswana as a period of unparalleled economic growth' (p1). The year 1993 marked a turning point in Botswana's economic development when the rate of economic growth declined from $6.5 \%$ in $1991 / 92$ to a modest $0.3 \%$ per annum in 1992/93 [7]. It was in 1994 that for the first time in the country's political history the opposition BNF made significant electoral gains by obtaining thirteen (13) parliamentary seats (about $37 \%$ of the total vote) with the BDP obtaining its lowest share of the vote since independence $(54.59 \%)$. According to the Botswana Institute of Development Policy Analysis (BIDPA) [8], it was during 1999 that the country reverted to the years of economic boom hence the improvement of the BDP vote from $54.59 \%$ to $57 \%$ and the BNF vote declining from $45.41 \%$ to $43 \%$.

The above scenario reduces the explanatory power of Molutsi and Holm [9] that Batswana do not make political choices on the basis of economic interests and/or considerations but rather on personalistic loyalties and tribal affiliation. Interestingly, Holm and Molutsi [10] contradictorily maintain that 'Botswana's rapid economic growth enabled government to provide significant returns to society and simultaneoulsy make the necessary capital investments' (p 81). As a consequence, they argue that economic issues have no potential to threaten the BDP electoral base. Matsheka and Botlhomilwe [6] attempt to make a case that the economic conditions that prevailed in 1994 suggest that society was economically weak and as such economic conditions are considered to have contributed in some measure to 
the electoral problems that the BDP encountered in that election year. The fact that 2009 was a year of economic crisis yet the BDP did not experience electoral defeat suggests that economic factors may be an important though not a sufficient condition to explain the BDP's electoral performance.

\section{The Influence of Seretse Khama}

The influence of Seretse Khama in the BDP's electoral success cannot be underestimated. Seretse was born into the Bamangwato Royal Family and was to assume the tribe's chieftaincy upon his return from further studies in Britain. However, as a result of his marriage to a British woman, a marriage that was opposed by the British colonial administration and his uncle Tshekedi Khama, he was denied the chieftaincy and banished. Botlhomilwe [11], among others, has it that the Bamangwato bitterly resented Seretse being denied the chieftaincy and the riots that erupted following his banishment bear testimony to his popularity among his people. When Khama formed the BDP, the Bamangwato were more than willing to support him. Henderson [12] argues that the Central District, where the Bamangwato are spread, is the largest district in the country and contains approximately 37 percent of the country's total population, such that Seretse, was from the very beginning, assured of massive electoral support. Henderson [12] further argues that Khama was a very influential leader combining the attributes of caution, guidance and political acumen and that the strength of modern-day Botswana owes much to his determination. According to Henderson [12], Khama possessed some advantages that made him appeal to almost the entire population. These advantages include, among other things, the fact that because of his personal history and descent, he became known throughout the country. He also had commitment and capacity to campaign in all parts of the country even in places where he was not welcome. Henderson [12] goes further to argue that Khama could also appeal to the chiefs' 'as an equal and though he didn't campaign much for their support, he did not go out of his way to alienate them' (p36).

At that time, chiefs were very powerful figures and had a lot of influence on their subjects and the subjects would normally support what their chief believed in. The fact that it was only Chief Bathoen II of Bangwaketsi who resigned his chieftaincy and joined the opposition BNF attests to the fact that the majority of chiefs, though dissatisfied at their loss of powers, were not hostile to Khama and his party. Henderson [12] observed that there is evidence from the chiefs themselves that Khama managed to manipulate the chiefs' fear of radical political parties for his own benefit. Another important advantage with Khama, though largely ignored in writings on his influence in the politics of Botswana, is the fact that he married a white woman. At the time of the marriage, apartheid was highly pronounced in neighbouring South Africa and it was a sort of an 'offence' for a black person to marry a white woman. When Seretse exposed the myth that a black person can not marry a white woman, he must have won the hearts of fellow black countrymen who regarded him as a sort of a 'hero'. In Tswana society, it is a rare privilege to marry a white woman and one earns a lot of respect on that account. This certainly has application to at least those black African societies that we know. Seretse's name is, to date, still a household name to the extent that it is not uncommon to hear a person, especially the elderly in rural areas, saying that he/she won't vote for opposition parties because Seretse (though late) would see that he/she is voting against his party. This goes to show the extent to which people in Botswana associate the BDP with the name of Seretse Khama.

\section{Advantages of Incumbency}

Probably the single most important factor behind the continued electoral success of the BDP has to do with the advantages that accrue to it by virtue of it being a party in power. It is not in dispute that over the years the BDP has exploited these advantages to its own benefit in the elections. Charlton [13] argues that consistent with what is happening in other African states, 'the exploitation of incumbency in Botswana involves the careful management of patron-client ties to cement mass-elite linkages and to channel economic success into BDP support' (p340). Although it may be argued that this is an unfair practice, it is doubtful if there is any political party that would behave otherwise when it is in power.

In the 1980s Botswana experienced a severe drought that resulted in poor harvests and the deaths of many cattle. In effect, the drought shattered the rural economy which relies heavily on pastoral and arable farming. The government came to the rescue of the rural population by introducing the Drought Relief Programme (DRP). The progamme involved, among other things, the creation of jobs through the introduction of labour intensive works such as dams, roads, classrooms, community halls and houses for extension workers in the rural areas. Tsie [14] argues that the introduction of this programme demonstrates the government's concern with the plight of the poor. This programme is still in existence and at present it is justified as a cushion against the adverse effects of the global current recession. Molutsi, cited in Charlton [13] contends that in policy terms, the single most important reason given by respondents for belonging to the BDP is the drought relief programme. According to Molutsi, through this programme, in which 'people were fed, subsidized, employed and assisted in so many ways, the ruling party has successfully resisted inroads to its popularity, especially in the rural areas' (p342). Holm and Morgan [15] maintain that 'The ruling Democratic party has recently come to see drought relief as a very effective means of reinforcing its rural support, the principal source of its majority' (p476). Charlton [13] holds the view that the 'distributional evenhandedness' of the ruling BDP has resulted in the ruling BDP gaining nation-wide support since people come to see it as government and thus the provider of resources, something which opposition parties lack. Charlton further asserts that:

Overall the system probably maximizes the BDP's aggregate vote, ensuring very respectable results even in seats consistently won by the opposition. No BDP candidate has polled below 28 percent of the vote, and a 30 percent vote is rarely seen. Normally, even when losing a seat, the BDP achieves over 40 percent support, giving the party a respectable chance of winning almost every election (p334).

Cabinet Ministers, Members of Parliament and Councillors also indirectly use their official positions to garner support for their party. The use of government resources to ad- 
dress Kgotla (Tswana traditional assembly) meetings in all parts of the country telling people about the achievements of the government and how the government will continue to help them advantages the BDP. This is especially important prior to a general election. The President too would embark on a country-wide tour to tell the electorate about the achievements of his government. While there is nothing wrong with ruling party ministers, parliamentarians, councilors and the president doing this, it is worth noting that these are the advantages enjoyed by the ruling party only. Opposition parties are thus at a great disadvantage. Although opposition councillors and members of parliament can (and do) use government resources to address their constituents in the Kgotla, they would, in effect, be selling the policies of the government of the day to the electorate. In esssence, this amounts to campaigning for the BDP. The opposition can not use the Kgotla forum to sell their ideas to the people since, at least theoretically, this forum is not supposed to be utilized for political campaigns but a place to discuss and inform the public about development issues.

In addition, the government controlled media, Radio Botswana and Botswana Television, have also contributed to the poor performance of the opposition. They give unfair coverage to the BDP especially where political rallies are addressed by the president and his deputy. This is at odds with the sentiments of Beetham and Boyle [16] that in particular the principle of fair competition 'requires that parties in government should be made to keep a clear separation between their government and party activities, and between the organs appropriate to it' (p10). Beetham and Boyle [16] also emphasise the fact that in a free and fair electoral system, electoral competition between political parties should be conducted on a playing field that is level. That is, political parties should have equal access to government resources or means of communication. According to Mmegi [17], when opposition parties recently complained about the bias of the government media against them, the director of Broadcasting Services argued that the opposition and the private media can not dictate the editorial content of the government press. Recently when the BDP was experiencing internal feuds, the same director personally read a statement from the BDP president on state television and radio informing the nation about the state of affairs in the BDP. This time the justification for the reading of the statement on the state media was that it was in the public interest. It is unclear as how problems bedeviling the BDP could possibly be in the national interest. Such problems are purely internal BDP issues. This is a clear demonstration of the inability to draw a distinction between the BDP and the government. The bias of the state media against opposition parties has a serious impact especially in view of the fact that none of the opposition parties owns a television, radio station or even a newspaper. Their ability to access potential voters is limited to the private press which has so far shown the willingness to accommodate them. Even then, the circulation of the private press is largely confined to urban areas. Private newspapers are also not free as is the case with the government media. Literacy rates in rural areas, where the majority of the population live, is low and to compound matters, private newspapers are written in English thus limiting the number of people who can read them.

\section{A Weak and Fragmented Opposition}

Opposition parties in Botswana are unable to offer a credible challenge to the ruling BDP. Sebudubudu and OseiHwedie [18] correctly assert that the "existence of political opposition is a good indicator of the degree of political tolerance in a country and paves the way for peaceful competition among political parties for the people's vote and government power' (p85). Political opposition in Botswana has, however, not been able to play the role ascribed to opposition political parties above. A number of factors can be advanced to explain this phenomenon. Opposition parties in Botswana are highly disorganized. Mtimkulu [19] reminds us that only orderly and well-organized organizations are more likely to succeed in their endevours. The major problem facing opposition parties in Botswana is lack of adequate financial resources. Financial resources enable political parties to reach the electorate and hence are essential for successful competition for political office. Bowler, Carter and Farrell [20] consider money to be one of the most important sources of political power. They argue that 'electoral success of political parties is more dependent on money than on access to the ballot or the media' (p111). While the BDP enjoys access to resources due to its ability to source funds as a result of it being in power, opposition parties do not have sufficient financial resources and this has serious implications on their ability to mobilize nation-wide support. The BDP has its own multi-storey headquarters that used to be rented out to government departments but is currently occupied by private companies. None of the opposition parties has a building of its own. The result is that opposition parties are organizationally weak. Polhemus [21] contends, rather sarcastically, that the sole visible sign of opposition parties during the early 1980s in Gaborone 'was a table set up occasionally by the BNF in the central shopping mall selling Koma's pamphlets, back issues of the African Communist, and raffle tickets'(p419). The situation still obtains today as opposition parties lack a fully fledged secretariat. They rely on the sacrifices of individual members and candidates to finance their political campaigns. This is unsustainable since Botswana has scattered populations and the country is very large, almost two and half times the size of the United Kingdom. This pathetic situation is not helped by the fact that the BDP has consistently refused the opposition proposal for public funding of political parties. It has recently emerged that the $\mathrm{BDP}$ has over the years received funding from the mining giant Debswana. This is the company that mines diamonds in Botswana and the Botswana government has a 50\% shareholding in the company. The implications of this revelation of funding, which has not been denied, are far reaching but beyond the scope of the present paper.

The other advantage of the BDP is that it can use its powers of appointment and co-optation to silence critics and potential critics. According to Good [22], such acts of manipulation undoubtedly weaken the opposition but are not atypical of liberalism. Sebudubudu and Osei-Hwedie [18] contend that the weakness of the opposition in Botswana can also be explained in part to their being prone to factionalism and fragmentation. They maintain that this factionalism and fragmentation greatly undermines the opposition's internal 
unity, public image and their ability to mobilize electoral support. This is particularly true with the BNF which has experienced serious splits especially in the run-up to general elections. For example, it experienced a serious split in 1998, just a year before the 1999 elections. Eleven of its thirteen members of parliament left the party and formed a new political party, the Botswana Congress Party (BCP). The split worked to the advantage of the BDP as the BNF was at pains to explain to the electorate what triggered the split and the BCP had very little time to campaign for the elections. The result was that the BDP managed to capture most constituencies held by the opposition. Prior to the 2009 elections, the $\mathrm{BNF}$ was once again embroiled in factional disputes that saw expulsions and suspensions of some prominent party members including sitting members of parliament. As a consequence, the BNF lost several seats to the BDP including those it held in its traditional stronghold of Gaborone, the capital city. Addressing the issue of factionalism and leadership struggles within the BNF, Wiseman [23] correctly stated that 'Whilst the prospect of actually winning power could induce instrumental unity within the party it could also provoke a set of squabbles over the fruits of victory before that victory had been obtained' (p260).

Some aspects of Tswana culture contribute to the weakness of the opposition and the continued rule of the BDP. According to Healey [24], traditionally, Batswana are fairly conservative and their culture involves 'a slow, patient and consensual approach to change' (p14). In the view of Roe [25], the conservative aspect of the Tswana culture results in part from a strong adherence to 'risk aversion' whose genesis is traceable to the traditional pastoral society which necessitated 'avoiding the perceived risks of living in a semiarid environment'(p349). According to Wiseman [23]:

Within this cultural context continuing support for a political party which was perceived as performing at least adequately in government avoided the risk involved in voting for a party, or parties, whose ability to govern remained conjectural at best. Unlike many African states Botswana never experienced the radicalizing (at least on a temporary basis) experience of a 'struggle for independence' (p254).

If Wiseman's analysis is correct, it then follows that the electorate in Botswana feel uncomfortable with voting for opposition parties in that the BDP has been reasonably successful in governing the country. They therefore would rather stick with the BDP than take the risk of voting for opposition parties which have never been tested in matters relating to governance.

There is little doubt that under the BDP the country has achieved remarkable rates of economic growth. Although we have argued that the electorate in modern Botswana seems to vote with economic considerations in mind, one would have expected the 2009 elections to be a good test for the accuracy of this argument. This is particularly pertinent in view of the fact that the country went to these polls in the middle of a serious economic recession. However, the recession did not result in the erosion of the BDP's vote. Sebudubudu and Osei-Hwedie [18] partially provide an answer to this question when they argue that:
More importantly, the problems in the economy have not reached crisis proportions so as to attract massive vote losses for the BDP, even in the face of the 2008 economic recession. The government has launched an aggressive drive to attract investment in order to create jobs and improve the chances of development, and has increasingly shown willingness to respond to the needs of the masses through service delivery and schemes targeted at the youth and unemployed graduates (p99).

Although the country went into the 2009 election in the midst of an economic recession, it should be noted that the recession had affected the whole world. In this sense it is a global recession. It therefore seems logical to argue that given the publicity associated with this economic recession, coupled with the efforts of the government to mitigate it through various schemes, the electorate must have understood that it was not of the government making and this is very likely to have influenced them to continue voting for the BDP.

The first-past-the post (FPTP) electoral system has also encouraged Botswana's one party-dominant system. There is consensus in the literature that this electoral system advantages large, ruling and dominant parties. Sebudubudu and Botlhomilwe [26] argue, for example, that:

The simple majority first-past-the-post system distorts representation in that losing parties, irrespective of their share of the popular vote, are technically shut out of government, with their participation limited to the few representatives who won seats. For example, in the latest election, the BDP won 53 percent of the popular vote while the opposition obtained 47 percent. This translated into 45 seats (or $79 \%$ of the seats in parliament) for the BDP, and only 12 for the opposition. The system therefore excludes smaller parties from fair representation and tends to exclude women and minorities from the legislature (p75).

Despite the dominance of the BDP, elections in Botswana have been relatively free. The electoral management body, the Independent Electoral Commission (IEC), although having some deficiencies such as its perceived lack of independence from the executive, as Balule [27] and Sebudubudu and Botlhomilwe [26] note, has been relatively successful in executing its mandate of election management. Electoral fraud has never been a feature of the politics of Botswana. Blatant executive interference in the activities of the IEC is virtually unheard of. This is in contrast to countries such as Zimbabwe where the last elections (2008) were flawed and in Nigeria where, according to Ijim-Agbor [28], the state leadership and the electoral body worked together to rig the 2007 elections.

\section{Performance of Parties in the 2009 Elections}

The 2009 elections did not produce any result that is significantly different from the previous elections. The BDP continued to dominate the outcome of the elections. Perhaps what is significant about these latest elections is that it was 
the first elections held under Ian Khama's presidency. The BDP, with huge resources at its disposal, was the only party that fielded candidates in all the 57 parliamentary constituencies. It won 45 of these constituencies with the opposition winning 13. An independent candidate, Nehemiah Modubule (Lobatse constituency), who had been expelled from the Botswana National Front (BNF) just before the elections, became the first independent candidate to win a parliamentary seat in the history of elections in Botswana. The BNF won 6 seats, followed by the BCP with 4, Botswana Alliance Movement (BAM) with 1 and an independent candidate winning 1 .

\section{Parliamentary Seats Contested and Won}

\begin{tabular}{|c|c|c|c|}
\hline Party & Contested & Won & Percentage \\
\hline \hline BAM & 4 & 1 & 1.75 \\
\hline BCP & 42 & 4 & 7.02 \\
\hline BDP & 57 & 45 & 78.95 \\
\hline BNF & 48 & 6 & 10.53 \\
\hline BPP & 6 & 0 & 0.00 \\
\hline BTTO & 1 & 0 & 0.00 \\
\hline IND & 15 & 1 & 1.75 \\
\hline MELS & 4 & 0 & 0.00 \\
\hline Total & 177 & 57 & 100.00 \\
\hline
\end{tabular}

Source: Independent Electoral Commission. 2009. Report to the Minister of Presidential Affairs and Public Administration.

As we have already argued, the FPTP electoral system has distorted party representation in parliament. The BDP won 53 percent of the popular vote while the combined opposition obtained 47 percent. The BDP representation translated into 45 seats (79 percent of parliamentary seats) while the opposition managed to win only 12 seats with 47 percent of the popular vote. Persistent calls by the opposition and some members of the ruling BDP for reforms in the electoral system have so far been resisted by the BDP.

\section{Post 2009 Elections and Future Prospects}

The BDP won the 2009 election yet it entered this election divided. In part the divisions had to do the leadership of the BDP president, Ian Khama. He is perceived as authoritarian and does not consult when making important decisions that have a bearing on the stability and performance of the party. Although Taylor [29] argues that Khama was brought into the presidency by former president Festus Mogae with the view to ending factionalism within the party, it appears the factionalism intensified under his leadership. The BDP had two factions: the so-called 'A-team' led by Jacob Nkate and Mompati Merafhe and 'Barata Phathi' (those who love the party) led by Daniel Kwelagobe and Ponatshego Kedikilwe. It would appear that this factionalism is a struggle for hegemonic influence within the party. Khama, for unknown reasons, is thought to be sympathetic to the former. Things came to a head during the run-up to the July 2009 party's congress that was to elect a new central committee.
In an apparent attempt to dilute the strength and influence of 'Barata-Phathi', Khama announced before the congress that he had made a decision that members of cabinet should not stand for central committee elections on account of the fact that holding two positions simultaneously hinders service delivery on the part of cabinet ministers. Surprisingly, this decision did not apply to him. He would still stand for the party presidency whilst holding the position of president of the country. Kwelagobe decided to sacrifice his ministerial position (Presidential Affairs and Public Administration) to stand for the party chairmanship. Others like Nkate and Merafhe decided to keep their cabinet posts. This move by Kwelagobe irked Khama who went on record maintaining that he can not work with Kwelagobe in the party and that Kwelagobe's health was failing. The campaign for central committee positions was so intense that despite the party policy of not attacking fellow party members in public, the president and members of the 'A-Team' publicly attacked members of 'Barata-Phathi' including their personalities. These attacks on each other by the two factions would have given an outsider the impression that they belonged to rival political parties.

In the July congress, Khama's favoured and/or preferred faction, the 'A-Team', suffered electoral humiliation, losing all substantive central committee elections, at the hands of 'Barara-Phathi' faction, though he (Khama) had publicly and actively canvassed support for them in the run-up to the elections. At the ceremony welcoming the newly elected central committee, Khama was conspicuously absent. He subsequently made unilateral appointments of additional central committee and party sub-committees members (largely drawn form the A-Team) without consulting the central committee as had been the customary practice in the party. This action by Khama did not go down well with the newly elected central committee. Through the Secretary General, Gomolemo Motswaledi, the central committee decided to seek legal opinion from three local law firms on the validity of some of the actions of the party president since the July congress. The action of the Secretary General in seeking legal opinion about the legality of Khama's action earned him a suspension from the party and central committee and banishment from standing for a parliamentary election in the Gaborone Central constituency. Khama accused Motswaledi of undermining his authority by attempting to challenge the legality of his decisions. Motswaledi challenged his suspension in the courts. His application was dismissed by both the High Court and Court of Appeal (the latter sitting in an emergency session) on the grounds that the head of state was immune from prosecution even in the exercise of duties outside his official domain whilst he was still in power. The Constitution of Botswana in Chapter 4, Section 41 states that "whilst any person holds or performs the functions of the office of President no criminal proceedings shall be instituted or continued against him either in his official capacity or in his private capacity and no civil proceedings shall be instituted or continued in respect of which relief is claimed against him in respect of anything done or omitted to be done in his private capacity'. This is the constitutional provision that gives the president total immunity against prosecution and it the provision that was invoked to dismiss Motswaledi's application for relief. To make matters worse, the BDP disciplinary committee with the blessing and apparent 
influence of the president, suspended him from the party for a period of five years. This suspension meant that he could not even stand for the 2014 elections under the BDP ticket. Motswaledi's suspension was the last straw in the BDP factional fights. He has since resigned from the BDP to join the new breakaway party, the Botswana Movement for Democracy $(\mathrm{BMD})$.

Agitated by what they believed to be Khama's dictatorial style of leadership, members of 'Barata-Phathi', including some sitting members of parliament, convened a meeting in March 2010 to discuss events within the BDP. The meeting heavily criticized the BDP and the country's leadership style and unanimously resolved to form a new political party as it was felt by members of this faction that their grievances could not be resolved under the current leadership. The new party, BMD, has been officially registered and was launched in a hugely successful inaugural convention held 29 May 2010 in Gaborone. Four sitting BDP members of parliament, Botsalo Ntuane, Wynter Mmolotsi, Gilbert mangole and Guma Moyo (who have now been expelled) and other prominent party members such as Sydney Pilane and Kabo Morwaeng, are some of the architects behind the formation of this new party. Sydney Pilane if the former Special Advisor to Ian Khama's predecessor, Festus Mogae. The formation of the party has caused so much panic within the BDP that the president has embarked on a tour of constituencies holding 'star rallies' in which he attempts to reassure the electorate that all is well within the BDP. With speculation rife that that the new party, numbers allowing, may forge an alliance with opposition members of parliament to pass a motion of no confidence on president Khama, the unease within the BDP is not without foundation. The 2014 elections are likely to provide a real test for the BDP predominance provided the opposition unite and avoid factional disputes which have become their hallmark.

It should be noted that this is the first time, since its formation, that the BDP has experienced a split of this nature and magnitude. This split is a direct result of Khama's inability to appreciate the fact that divergent views are not antithetical to democracy as he seems to believe. It is intolerance that works against the spirit of democracy. In voluntary associations such as political parties, there are bound to be conflicts and disagreements on a number of issues and toleration is the best solution to such disagreements. This is precisely why Scalcon [30] is instructive when argues that:

...toleration involves a more attractive and appealing relation between opposing groups within a society. Any society, however homogeneous, will include people who disagree about how to live and about what they want their society to be like. (And disagreements within a relatively homogeneous culture can be more intense than those within a society founded on diversity, like the United States). Given that there must be disagreements, and that those who disagree must somehow live together, is it not better, if possible, to have these disagreements contained within a framework of mutual respect? The alternative, it seems, is to be always in conflict, even at the deepest level, with a large number of one's fel- low citizens. The qualification "even at the highest level" is crucial here. I am assuming that in any society there will over time be conflicts, serious ones, about the nature and direction of the society. What toleration expresses is recognition of common membership that is deeper than these conflicts, a recognition of others as just entitled as we are to the definition of our society (p231).

Any attempt by the leadership to push people out of party positions for the simple reason that their views are inconsistent with those of the party leader is not only undemocratic but also borders on authoritarianism.

\section{CONCLUSION}

This paper has argued that that the BDP has been chronologically dominant in Botswana's political landscape since the pre-independence elections of 1965. The latest election of 2009 was a continuation of the same trend. This has made elections in Botswana a ritual as the country remains a predominant party system. A number of factors have been advanced to explain the dominance of the BDP in the country's electoral politics. These include, inter alia, the influence of the founding president, Seretse Khama, the advantages of incumbency, inadequate resources at the disposal of opposition parties, and the fact that opposition parties are prone to fragmentation especially in the run-up to elections. It has also been argued, however, that the recent split of the BDP and the subsequent formation of the BMD present a great opportunity for the emergence of a formidable opposition capable of removing the BDP from power. This, it is hoped, will signal the end of the system of one-party dominance in Botswana in the 2014 general election. The formation of the BMD is a significant development since it represents the first time in its history that the BDP has experienced a split that has given birth to a new political party. It is also a lesson to political leaders that consultation and tolerance are essential for the unity and stability of political parties. Even then, the BDP may use the incumbency advantages to halt the challenge the new breakaway party may pose to its dominance. However, the performance of the BMD and other opposition parties will be determined by "chance events" and how they coalesce for support.

\section{ACKNOWLEDGEMENT}

The authors would like to thank the anonymous reviewers for reading and making suggestions that improved this paper.

\section{ACRONYMS}

$\begin{array}{ll}\mathrm{BAM} & =\text { Botswana Alliance Movement } \\ \mathrm{BCP} & =\text { Botswana Congress Party } \\ \mathrm{BDP} & =\text { Botswana Democratic Party } \\ \mathrm{BIDPA} & =\text { Botswana Institute of Development Policy } \\ & \text { Analysis } \\ \mathrm{BMD} & =\text { Botswana Movement for Democracy } \\ \mathrm{BNF} & =\text { Botswana Democratic Party } \\ \mathrm{BPP} & =\text { Botswana People's Party }\end{array}$




$$
\begin{aligned}
& \text { DRP }=\text { Drought Relief Programme } \\
& \text { FPTP }=\text { First-Past-The-Post } \\
& \text { IEC }=\text { Independent Electoral Commission } \\
& \text { IND }=\text { Independent Candidate } \\
& \text { MELS }=\text { Marx Engels Lenin Stalin } \\
& \text { REFERENCES }
\end{aligned}
$$

\section{REFERENCES}

[1] Dalton RJ, Gray M. Expanding the electoral marketplace. In: Cain BE, Dalton RJ, Scarrow SE, Eds. Democracy transformed: expanding political opportunities in advanced industrial democracies. Oxford, England: Oxford University Press 2003; pp.23-43.

[2] Savage M, Warde A. Urban sociology, capitalism and modernity. London, England: Macmillan 1993.

[3] Kotze H, Garcia-Rivero C. Opposition and party support in Africa: an elite-mass analysis. Gov Oppos 2008; 43(3): 454-85.

[4] Swank OH, Eisinga R. Economic outcomes and voting behaviour in a multi-party system: an application to the Netherlands. Public Choice 1999; 101(3-4): 195-213.

[5] Johnson P, Pattie C. Feeling good and changing one's mind: a longitudinal investigation of voters' economic evaluations and partisan choices. Party Polit 1999; 22(6): 39-54.

[6] Matsheka TC, Botlhomilwe MZ. Economic conditions and election outcomes in Botswana: is the relationship spurious? Pula 2000; 14(1): 36-46.

[7] Bank of Botswana. Annual reports. 1989, 1994, 1998.

[8] Botswana Institute of Development Policy Analysis. Quarterly review 1999.

[9] Molutsi PP, Holm JD. Developing democracy when civil society is weak: the case of Botswana. Afr Affairs 1990; 89 (356): 323-40.

[10] Holm J, Molutsi PP. State-society relations in Botswana: beginning liberalization. In: Hyden G, Bratton M. Governance and politics in Africa. Boulder and London, England: Lynne Reinner 1992.

[11] Botlhomilwe MZ. The emergence of electoral support for the opposition in Botswana. Lancaster: Lancaster University 1997.

[12] Henderson W. Seretse Khama: a personal appreciation. Afr Affairs 1990; 89(354): 27-56

[13] Charlton R. The politics of elections in Botswana. Africa 1993; 63(3): $330-70$
[14] Tsie B. The political context of Botswana's development performance. J S Afr Stud 1996; 22(4): 599-616.

[15] Holm JD, Morgan RG. Coping with drought in Botswana: an African success. J Mod Afr Stud 1985; 23(3): 463-82.

[16] Beetham D, Boyle K. Introducing democracy: 80 questions and answers. Cambridge, England: Polity Press 1995.

[17] Mmegi (Botswana), 5 March 2010.

[18] Sebudubudu D, Osei-Hwedie. In permanent opposition: Botswana's other political parties. SAJIA 2010; 17(1): 85-102.

[19] Mtimkulu P. The key to one-party dominance: a comparative analysis of selected states: some lessons for South Africa. JAE 2009; 8(2): 23-45.

[20] Bowler S, Carter E, Farrell DM. Changing party access to elections. In: Cain, BE, Dalton RJ, Scarrow SE, Eds. Democracy transformed: expanding political opportunities in advanced industrial democracies. Oxford, England: Oxford University Press 2003.

[21] Polhemus JH. Botswana votes: parties and elections in an African democracy. J Mod Afr Stud 1983; 21(3): 397-430.

[22] Good K. Interpreting the exceptionality of Botswana. J Mod Afr Stud 1992; 30(1): 69-95.

[23] Wiseman JA. The slow evolution of the party system in Botswana. Asian Afr Stud 1998; 33(3): 241-64

[24] Healey J. Botswana: a study in political accountability. In: Healey, J, Tordoff W, Eds. Votes and budgets: comparative studies in accountable governance in the south, London, England: Macmillan 1995; pp. 13-62.

[25] Roe EM. Individualism versus community in Africa? the case of Botswana. J Mod Afr Stud 1988; 26(2): 347-50.

[26] Sebudubudu D, Botlhomilwe, MZ. The management of elections: the case of Botswana. Politeia 2010; 29(1): 65-77.

[27] Balule T. Election management bodies in the SADC region-an appraisal of the independence of Botswana's independent electoral commission. South Afr J Hum Rights 2008; 24(1): 104-22.

[28] Ijim-Agbor U. The independent Nigeria national election commission as an (im) partial umpire in the conduct of the 2007 elections. JAE. Special Issue: Nigeria's 2007 General Elections 2007; 6(2): 74-94.

[29] Taylor I. Growing authoritarianism in the "African miracle"-should Botswana be a cause of concern? 2005. DIS Working Paper no 2005/24.

[30] Scalcon TM. The difficulty of tolerance. In: Heyd D, Ed. Toleration: an elusive virtue. Princeton, United States of America: Princeton University Press 1996; pp. 226-39.

This is an open access article licensed under the terms of the Creative Commons Attribution Non-Commercial License (http://creativecommons.org/licenses/ by-nc/3.0/) which permits unrestricted, non-commercial use, distribution and reproduction in any medium, provided the work is properly cited. 